\title{
Historical contamination and brownfield management: what does economic theory say about it?
}

\author{
S. Čiháková Aguilar, M. Černíková \& M. Dubová \\ Institute of Novel Technologies and Applied Informatics, \\ Technical University of Liberec, Czech Republic
}

\begin{abstract}
Residuals from past industrial, mining or military activities might represent a variety of hazards for natural ecosystems. Depending on the location of such areas, environmental assessment will be needed in order to determine if the concentration of pollutants is above the acceptable levels and can become a clear threat for human health. Furthermore, it becomes important to notice that the quality of natural resources can be directly affected. The detriment of the quality of human health and natural resources can also be translated into worse living conditions for certain inhabitants.

The redevelopment of contaminated areas where it is also difficult or impossible to identify the original polluters may incorporate an analytical background not just on legislative and technical issues. Economic theory has principles and paradigms that can explain different approaches towards the effective management of brownfields.

The scope of this work is to describe how various schools of economics focus their study on environmental problems, specifically on brownfield redevelopment. After an introductory part with definitions and a general framework, the paper presents the ideas of environmental economics, free market environmentalism, institutional economics, and ecological economics. Each part is complemented by an overview of empirical research in the field of historical contamination.
\end{abstract}

Keywords: historical contamination, brownfields, economic theory, free market environmentalism, ecological economics, environmental economics, institutional economics. 


\section{Introduction}

The presence of brownfields can affect both urban and natural areas, and therefore will influence not only specific economic activities of people located in their surroundings, but also might become a hazard for natural resources and people's health. Economic theory can serve as a useful tool for understanding many relations originating as a result of brownfields: Past activities vs. present damage; remediation costs vs. benefits; brownfields vs. greenfields development; costs for nature protection vs. investment in other sectors. This part makes an overview of the schools and disciplines related to economic theory whose principles might be applied to the study, management and valuation of brownfield issues. The theoretical framework of each discipline mentioned is complemented by some results of empirical studies.

\section{Environmental economics}

Environmental economics can be defined as a discipline that incorporates the environment as the main subject of the economic analysis. It follows mainly the marginalistic perspective of neoclassical economics. According to this discipline, environmental problems appear due to the existence of market failures and externalities.

The analysis of externalities and distribution of resources are based on economic and quantitative terms, as a function of prices, costs and monetary benefits. These types of analyses also suggest the application of tools in order to regulate the imbalance nature vs. economy.

The traditional instruments for environmental regulation recommended by environmental economists tend to indicate "command and control" measures such as environmental regulations, and the application of taxes and tariffs on pollution, originally based in the analysis of welfare economics of negative externalities from Pigou [1].

According to the neoclassical approach environmental problems should be solved at a level that allows the maximum benefit at the least amount of abatement costs. Economically speaking, the "efficient" level of pollution is recognized at the point at which marginal damages equal marginal abatement costs. Figure 1 illustrates the neoclassical concept of pollution level efficiency. The optimal pollution level is denoted by point $O P$.

While trying to follow the way of the curve of the damages, environmental economics might want to set up a monetary expression for the lack of satisfaction that subjects of the society put for decrements of environmental quality within issues related to brownfields. This can also be seen as the calculation of the demand curve for environmental goods with information on the prices that consumers pay or are willing to pay for the goods. Environmental amenities are not bought and sold in the market, and therefore do not reflect a direct market value.

As mentioned above, neoclassical economics deals with this issue with tools approaching monetary values to non market goods. The methodologies used for 


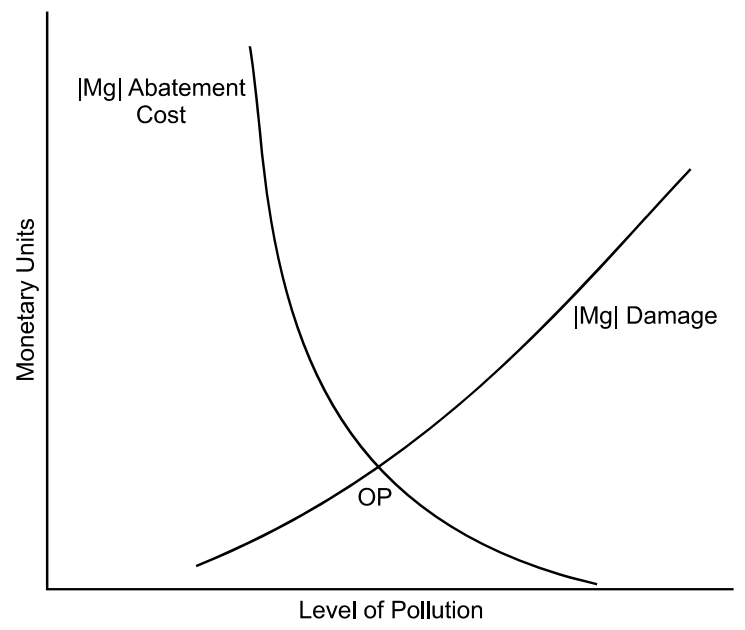

Figure 1: Optimal level of pollution. Environmental Economics Perspective (Sauer [2]).

these estimations in the branch of brownfields can vary from benefit transfer methods, to non market valuation methods such as hedonic pricing, and contingency valuation among others.

\subsection{Hedonic pricing}

This method suggests finding a demand curve of environmental amenities through the characteristics (qualities) that are included in an entire land property package.

As observed in different studies, valuation of damages related to brownfields tends to be done through hedonic pricing methods. Svetlik [3] presents the results of the study using the hedonic land pricing technique to identify the determinants of land prices in Monongalia County, WV, and investigates the impacts of local brownfields on residential property values. The study presents a strong negative correlation between the presence of a small dump as a brownfield and the price of housing in the town observed. The author concludes that the configuration of the landscape is a major contributor to the quality of life. Land use patterns are synonymous with location attributes, such as aesthetics, congestion, and convenience.

Hedonic pricing methods may contain limitations such as the appearance of heteroskedacidity in samples of different distributions and also of multicollinearity, thus the presence of effects which may not precisely have been caused by variables included into the model. If, for example one just includes the presence of brownfields in the proximity of a residential zone as an independent variable, and this appears to be negatively correlated with the housing prices, and 
forgets to include other factors, such as employment or leisure opportunities, etc., it is not valid to conclude that brownfields influence the housing market in such a zone.

Such errors should be identified, tested, clearly mentioned in the reports of results and then corrected if possible.

More applications of hedonic pricing related to brownfields try to find connections between the value of a site and the way brownfields' cleaning up is being treated. According to Greenstone and Gallagher [4], an explicit market for a clean local environment does not exist. This is the reason why the hedonic price method is commonly used to infer the economic value of non-market amenities like environmental quality to individuals. In one of his working papers he uses the hedonic pricing through housing market to develop estimates of the local welfare impacts of Superfund sponsored clean ups of hazardous waste sites (The 1980 Comprehensive Environmental Response, Compensation, and Liability Act, which became known as Superfund, gave the EPA (USA) the right to place sites that pose an imminent and substantial danger to public welfare and the environment on the National Priorities List (NPL) and to initiate remedial clean ups at those sites). The foundings of type research show that the estimated costs for the remediation of the sites are too high in correspondence to the welfare of individuals living in the sourroundings of these related sites.

\section{Free market environmentalism}

Some authors reject government intervention in environmental issues because of the fundamental reason that these kinds of interventions may not reflect a transparent compromise towards environmental protection. On the contrary, the forces of market and free decision-making processes could present better results for the individuals including the environment and even achieving more effective forms of protection of nature.

Free market environmentalism has adopted the basic ideas of the Austrian School of Economics, whose main representative (Hayek [5]) claims to the attention, that governmental intervention may limit freedom, which could become dangerous for the natural development of human principles in democratic societies.

Free market environmentalism does not support the idea of interventionism through taxation or any kind of environmental regulation. The solution to environmental problems should be left in the hands of a well designed system of property rights. Empirical studies on the area try to show the (in)efficiency of state regulations while trying to achieve improvements in environmental performance.

The trend of a centralized treatment of environmental issues around the management of brownfields has attracted the attention of representatives of free market environmentalism.

Empirical studies encourage the implementation of free market tools in order to achieve the solution of determinate environmental problems. 
The criticism and skepticism towards the efficiency of the U.S. Superfund is one of the clearest and more recent examples of the disagreement of government interventionism within the framework of cleaning-up processes and restoration of brownfields.

In Shawn [6] the US brownfields legislation is defined to "take away states' freedom to clean up sites to their specifications" - Stroup [7] criticizes the great amount of transaction costs and thus the evident inefficiency of CERCLA in achieving its original goals He argues that the main weakness of the program is its general and global character. The inefficiency issue has not been solved even with the attempt to lessen transactions costs with the reduction of bureaucracy through the introduction of more flexible rules for budgetary reports and controls. In other words, according to the author, federal laws have a strong potential for corruption and are also not able to solve local and specific problems related to contaminated sites. Thirteen years after, Mailman [8] presents another mechanism out of the free market framework: the U.S Bankruptcy Code. The author describes it as one of the treats for the Superfund's effectiveness for the achievement of its goals: According to ASCE and its study called the "Report Card for America's Infrastructure" the rate of Superfund site clean-up has improved up to 2003, but it is not able to keep up with the rate at which new and potential sites are identified.

In Hamilton and Viscusi [9], health risks and population exposures are compared with the costs of the US Superfund. The conclusions of the analysis reflect excessive costs for remediation with irrelevant concrete improvements in the field of health protection, mainly on the prevention of cancer. In this study the authors point out that that governments do not necessarily come to permanent remedies when they bear the costs.

In Nugent [10], the author presents alternative ways for the development of brownfields.

His innovative idea of "cleaning soil with mushrooms" suggests that there can be always an alternative to the management of environmental goods. According to the author, it is not feasible (and also not necessary) to clean up completely one site nor all the contaminated sites, as EPA's policy intends to do. Therefore, one may look for attractive economic activities that keep people motivated to cooperate, finding the solutions that can give practical solutions and clear results for the individuals affected. Nugent says his company can gain a profit while using environmentally friendly technology on residential properties or former military sites.

\section{New institutional economics}

The research of new institutional economics has partially started as a reaction to welfare and mainstream economics, mainly to Pigou's conception of externalities in Coase [11]. Thanks to the concepts of Coase [12], new institutional economics (NIE) acknowledges the existence of transaction costs and their influence on economic and environmental outcomes. Instead of the idea 
of externalities, which Paavola and Adger [13] consider as a narrow concept, NIE is characterized by the broader concept of interdependence.

The application of NIE in brownfield management can be perceived through studies which observe and evaluate the institutional framework within specific locations. Brownfield management initiatives correspond traditionally to centralized decisions from different legislative frameworks. The cases presented below are mainly focused on the analysis of governance characteristics and information issues.

The case presented by Williams and Dair [14] reflects how generally oriented policies are not able to "encourage" companies in order to achieve "general goals". The observations made by the authors conclude that the limitations regarding the sustainability of brownfield development correspond mainly to the characteristics of the stakeholders' participation. They identified these five "main barriers" as follows:

- Stakeholders' omission of sustainability as an element of a 'successful' project.

- Inadequate participation by relevant stakeholders.

- Inappropriate timing of stakeholders' participation.

- Lack of powers to enforce the rise of sustainability options.

- Resistance to the use of sustainable technologies and materials.

It can be inferred from this study that the decision making process entered in conflict of goals definition, since engagement to achieve the general goals has not been reflected within the firms in charge of cleaning-up.

Meyer and Estrin [15] apply a combination of resource-based and transactioncost theories in order to analyze three market entry modes for firms' expansion strategies: conventional acquisitions, greenfields, and brownfields. The authors identify brownfields as a hybrid mode of acquisition and found after observation of various studies, that firms tend to choose the acquisition of brownfield if it can provide them with already established local assets which can be combined with their competences. It becomes more attractive for companies to acquire the infrastructure of former firms so they can take advantage of certain established local characteristics and eventually "redo" the whole production concept than to risk in investments in "new land" such as greenfields, where the market is not necessarily defined. The conventional acquisition process also might represent a variety of trade-offs between both companies. The paper also suggests the following definition for brownfields "a brownfield is a foreign acquisition undertaken as part of the establishment of a local operation. From the outset, its resources and capabilities are primarily provided by the investor, replacing most resources and capabilities of the acquired firm". It can be inferred from the paper that the authors do not assume environmental issues as a risk factor for the acquisition of brownfields, since they suggest this entry mode as an opportunity to expand in economies where the institutional frameworks are weak (and there is therefore less environmental awareness and/or control). They also suggest 
undergoing a benchmark of the motivations for existing entry modes applied in different locations.

The study pursued by Bluffstone [16] gives results of empirical research in various privatized companies within five central European countries (Hungary, Lithuania, Poland, Romania and Slovakia). The goal of the study was to identify if there is a connection (and therefore a correlation) between the conclusion of a remediation process and the existence of information and plans about environmental analyses prior to and after the privatization process. The hypothesis was evaluated through econometric models. The results indicate that not only the existence of appropriate environmental information before privatization is a key issue for the development of further decontamination processes, the author found that it is also essential to combine it with environmental audit plans. One of the limitations of the analysis is that there is no data on the quality levels of the remediation, but shows also interesting additional issues about the region studied. For example, the author points out that at the time of the first (and the most) cases of privatization - in the years 1990-91 - the countries included in the study had limited laws and policies for addressing environmental liabilities during the process of property transfer, which influenced that mass privatization put off environmental problems "for the future" when the owner would be forced to face the liabilities they had ignored before. The author also observed through the results that up until 1998, pollution and site contamination issues may have been handled informally.

Reports, such as the Great Lakes Commission [17], have recapitulated and observed data concerning brownfields management in specific regions. This study mentions how public participation for brownfield development has been addressed in the U.S. Great Lakes Region. It is observed that the most common public participation element in the region is notification. According to the authors, the sole fact that an announcement is placed in local newspapers is important but represents just a little piece of a comprehensive plan for public involvement.

\section{Ecological economics}

Ecological economics is a discipline whose origins correspond mainly to the reaction to the ideas of environmental economics. Ecological economics reject the concept of the natural environment only by means of its use and option values for human beings and thus, considers that is necessary to include not only human needs in the evaluation and management of ecosystems. It is focused on the intrinsical value of nature and therefore has an ecocentric approach. According to Costanza et al. [18] the objectives of study of this discipline are a wider understanding of the complex interrelationships between the economic, social and environmental systems in order to find solutions to conflicts existing within these systems.

Differently from free market environmentalism, ecological economics believes in the power of a centralized environmental policy which can support programs towards the achievement of the maximum protection of environmental 
amenities according to limits set by natural scientists. The evaluation of such actions will be developed mainly under the results of cost-effectiveness analysis. A cost effectiveness analysis is able to show the ratio at which money expenditures are related to expected results for specific areas. In other words, ecological economics might develop studies trying to find the cheapest way of achieving the desired environmental target.

The empirical work of ecological economics in the branch of brownfields includes quality assessments for projects concerning urban planning as, for example, Nijkamp and Rodenburg [19], or applications of specific systems such as GIS in Geoghegan et al. [20], suggesting wider approaches for natural valuation than the neoclassical ones (hedonic pricing).

Another close approach to the analysis of ecological economics in the brownfield area can be found in studies concerning the application of industrial ecology.

Industrial ecology is a broad, holistic framework for guiding the transformation of industrial systems from a linear model to a closed loop model that resembles the cyclical flow of ecosystems. Unlike the traditional linear model of economics, the industrial ecology model, through a systems perspective, seeks to optimize overall efficiency, ultimately eliminating all waste. Industrial ecology aims to reduce the overall environmental impact of an industrial system through the selection and optimization of the elements of the organizational system and its interaction. Industrial ecology can therefore be seen as an integrated system's approach to managing the environmental effects relating to energy and material consumption and capital generation in industrial systems. Industrial ecology encompasses the concept of cleaner production, whereby cleaner production focuses on waste reduction within a single organization. However, through an interdependent system of industrial organizations, thus modeling a natural habitat, it is hoped to achieve lower environmental impacts and a better exploitation of resources.

Eilering and Vermeulen [21] focus on the presentation of different case studies in the Netherlands about the implementation of eco-industrial parks. (An eco-industrial park is a community of companies, located in a single region, that exchange and make use of each other's by-products or energy Desrochers [22].) The study explicitly defines the design of eco-industrial parks as one of the concrete applications of industrial ecology. Additional to the traditional advantages that systems of interdependent companies and factories can create cooperation, the authors conclude after their observations that eco-industrial parks helped to achieve significant reductions of environmental burden and should be taken into account as alternative models for brownfield redevelopment.

According to Martin et al. [23], industrial ecology may focus on a twodimensional analysis that includes the locality's stage of development and its degree of business concentration. The authors suggest promoting industrial parks in areas where development already exists and business concentration is lower. Figure 2 illustrates this idea of presenting brownfields as one of the most suitable areas for the creation of industrial parks. 


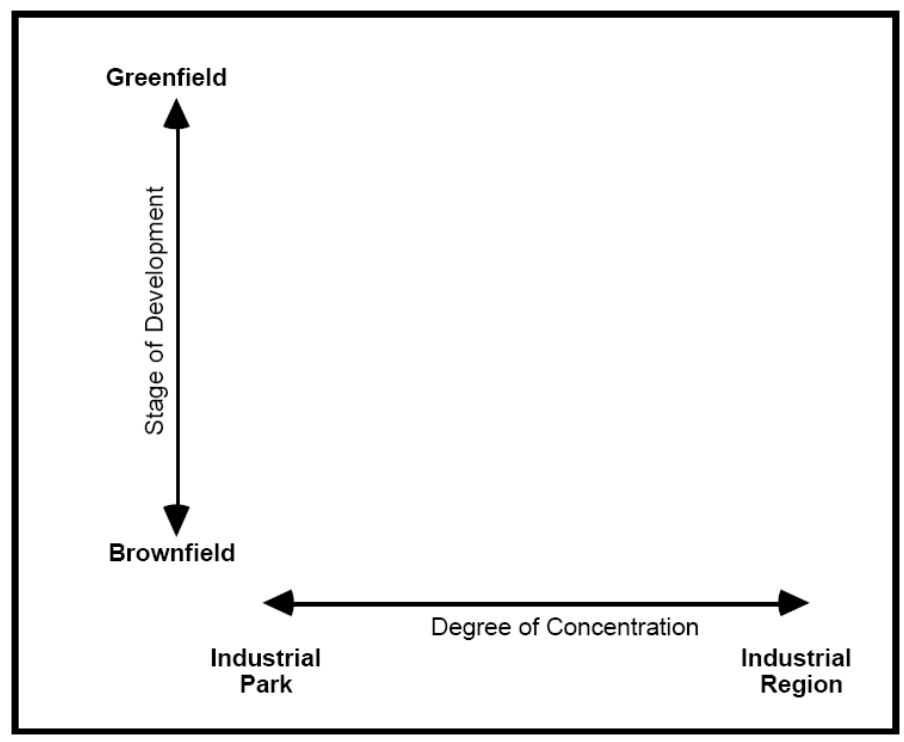

Figure 2: $\quad$ Industrial ecosystems (Martin et al. [23]).

\section{Conclusions}

One can identify notable differences in the application of economic theory towards the management of brownfields, depending on specific schools of thought. Neoclassical economics, through the study of environmental economics focuses on the utilitarian approach and tend to promote the use of command and control measures in order to achieve the "pollution optimum". Free market environmentalism does not support the government interventionism and suggests, on the other hand, market oriented solutions reflecting the freedom of decisions made by affected stakeholders. New institutional economics make assessments of the success of institutional arrangements towards the resolution of environmental conflicts among affected parties. Ecological economics underline the importance of a multidisciplinary and global approach in order to achieve not only economically efficient solutions, but also ecologically effective ones.

Even if the studies presented do not clearly expose which school they belong to, we made an effort in order to classify them according to the methods used and instruments proposed in their conclusions.

The most common supporting disciplines and techniques for the economics of brownfields encountered for the purposes of this work included cost-benefit analysis, analysis, hedonic pricing, regression analysis, cost-effectiveness multicriteria analysis, and qualitative research.

The prevailing point within the economic theory applied to brownfield redevelopment in this work was the management of conflicts. Each school tries to approach historical contamination in different ways, but for all economists 
environmentally risky brownfields are particular because they lack "original responsible subjects" for the pollution created in the past, which makes the problem become a "common present one".

\section{Acknowledgement}

This article was created under the state subsidy of the Czech Republic within the Research and Development project "Advanced Remediation Technologies and Processes Center" 1M0554 - Programme of Research Centers supported by the Ministry of Education.

\section{References}

[1] Pigou, A.C. The Economics of Welfare, London: Macmillan, 976 p. 1920.

[2] SAUER P. "Ekonomické souvislosti řešení ekologických důsledků pobytu sovetských vojsk na našem území”, Acta Oeconomica Pragensia, č.2/1993.

[3] Svetlik, J. B. Externality Effects of Local Brownfields on Residential Property Values. Northern West Virginia Brownfields Assistance Center, West Virginia Water Research Institute Morgantown, WV. Paper presented at the 2007 Business of Brownfields Conference, in Pittsburgh, PA. 2007. Online http://www.eswp.com/PDF/Svetlik_BFpropvalues07.pdf

[4] Greenstone, M., Gallagher, J. Does Hazardous Waste Matter? Evidence from the Housing Market and the Superfund Program. MIT Department of Economics Working Paper No. 05-27. Online http://ssrn.com/ abstract $=840207$. Massachusetts 2007.

[5] Hayek, F. The Fatal Conceit: The Errors of Socialism. Routledge. London, 194 pp. 1989. ISBN 978-0226320663.

[6] Shawn, J. S. Not Quite A Gentleman. The Environmental Forum. The Environmental Law Institute, Washington, D.C. 2003. ISSN 0731-5732.

[7] Stroup, R.; Townsend B. EPA's New Superfund Rule: Making the Problem Worse. Regulation: The Cato Review of Business \& Government No. 3, Washington, D.C .1993.

[8] Mailman, R. Cleaning Up Its Act: Improving CERCLA Efficiency within the Bankruptcy Code. 27 Whittier Law Review. Whittier CA. Vol. 27; No. 2, pp. 557-596 2005. ISSN 0195-7643.

[9] Hamilton, J.; Viscusi, W. Calculating Risks: The Spatial and Political Dimensions of Hazardous Waste Policy. The MIT Press .Cambridge, Mass., 340 pp. 1999. ISBN 978-0262082785.

[10] Nugent, S. Mushrooms Meet Brownfields. A Market for Fungal Remediation. PERC Reports. Volume $24 \mid$ Number 4. Washington DC 2006. Online http://www.perc.org/articles/article847.php

[11] Coase, R. The Problem of Social Cost. Journal of Law and Economics, Vol III. pp. 1-44. 1960. ISSN 00222186.

[12] Coase, R. The nature of the firm. Economica, Vol. IV. pp. 386405.1937.1920. ISSN 0013-0427. 
[13] Paavola J., Adger N. New institutional economics and the environment: conceptual foundations and policy implications. CSERGE Working Paper. University of East Anglia, Norwich 2002. Online http://www.uea.ac.uk/env/cserge/pub/wp/edm/edm_2002_06.pdf

[14] Williams K., Dair C. Five barriers to sustainable brownfield development. Town and Country Planning, Vol .72, No. 11. pp. 344-345. 2003. ISSN 0040-9960.

[15] Meyer, K. Estrin, S. Brownfield Entry in Emerging Markets. Journal Of International Business Studies. Palgrave. Hampshire. Vol. 32. No. 3, pp.575-584.2001. ISSN 0047-2506.

[16] Bluffstone, R. Privatization and contaminated site remediation in Central and Eastern Europe: Do environmental liability policies matter? Ecological Economics, Elsevier, vol. 63. No. 1. 2007. p. 31-34. 2007. ISSN 0924-6460.

[17] Great Lakes Commission. Linking Brownfields Redevelopment and Greenfields Protection for Sustainable Development. 2001. Online http:/www.glc.org/bridges/9-01BridgesI.pdf

[18] Costanza, R., Cumberland J., Daly H., Goodland R., Norgaard R. An Introduction to Ecological Economic (Hardcover) CRC Press. 275 p. 1997.

[19] Nijkamp, P., Rodenburg, A. Success factors for sustainable urban brownfield development A comparative case study approach to polluted sites. Ecological Economics, Vol. 40, p. 235-252. 2002. ISSN 0921-8009.

[20] Geoghegan, J., Wainger, L., Bockstael, N. Spatial landscape indices in a hedonic framework: an ecological economics analysis using GIS. Ecological Economics, Vol. 23, No. 3, pp.251-264. 1997. ISSN 0921-8009.

[21] Eilering, J., Vermeulen, W. Eco-Industrial Parks: toward industrial symbiosis and utility sharing in practice. Progress in Industrial Ecology Vol. 1, No. 1-3. 2004. ISSN 1478-8764.

[22] Desrochers, P. Eco-Industrial Parks. The case of private planning. In Rethinking Green. Alternatives to Environmental Bureaucracy. Edited by Higgs and Close. The Independent Institute. Oakland. 2004. pp. 297-324. ISBN 0-945999-97-6

[23] Martin, S., Weitz A., Cushman, R., Sharma, A., Lindrooth, R., Moran, S. Eco-Industrial Parks: A Case Study and Analysis of Economic, Environmental, Technical, and Regulatory Issues: Final Report. Research Triangle Park, NC: Research Triangle Institute. 1996. 274 pp. Online http://www.rti.org/pubs/case-study.pdf. 